F 593
T5 U6
913
opy 1 



\section{ERADICATION OF CATTLE TICK}

\section{HEARING}

BEFORE THE

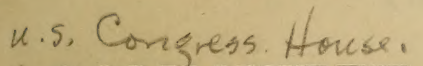

¿ COMMITTEE ON AGRICULTURE,

HOUSE OF REPRESENTATIVES

ON

\section{ERADICATION OF THE CATTLE TICK}

JANUARY 3, 1913

WASHINGTON

GOVERNMENT PRINTING OFFICE

1913 


$$
\begin{array}{r}
S F 593 \\
.5416 \\
1913
\end{array}
$$

D. AF 0 ,

MAE $26 \quad 1915$ 


\section{ERADICATION OF CATTLE TICK.}

Committee on Agriculture,

House of Representatives,

Washington, D. C., January 3, 1913.

The committee met at 10.30 o'clock a. m., John Lamb (chairman) presiding.

The Chairman. Gentlemen of the committee, we have with us this morning some gentlemen appearing in the interests of agriculture in the South, who wish to present to us their views touching appropriations for the eradication of the Texas fever tick. They ask for an increase of this appropriation over our estimates. These gentlemen have some newly discovered testimony, as a lawyer would say, I think. The committee will gladly hear from the gentlemen present. Who will you have first ?

Mr. Clayton. I may suggest that our friend, Mr. Graham, of North Carolina, has been before the committee frequently heretofore on this same subject and he is present-he is commissioner of agriculture of that State; and Capt. Kolb, the commissioner of agriculture of Alabama; then the commissioners of agriculture of Mississippi and the other Southern States, I believe, are all present here by their commissioners of agriculture or by somebody from the department of agriculture of their respective States. In addition to these gentlemen we have here present gentlemen whose business is of a scientific nature; that is veterinary surgeons. We have here Dr. Cary, of Alabama, a distinguished veterinary scientist, and I I would suggest that Capt. Kolb and Mr. Graham agree among themselves with their associates as to the order of the hearing.

\section{DR. C. A. CARY, STATE VETERINARIAN OF ALABAMA, OF AUBURN, ALA.}

Dr. CARy. We held a meeting of our committee last night and we designated certain members of it who are scientific veterinarians and shall be glad if the committee will hear from them first.

The Chatrman. Capt. Cary, I wish to say to you that we have two hearings this morning and we can give you only until a quarter past 11 o'clock.

Mr. Clayton. Dr. Cary tells me they have agreed on a program, and I suggest, Mr. Chairman, that Dr. Cary present that program and that this committee follow it in its hearings to-day.

Dr. CARY. I will state to this committee that our committee which is appearing before you is a committee appointed by the Association of Southern Agriculturists at a meeting held at Raleigh the latter part of November, and we have arranged a definite order under which we wish to present this subject to you this morning. 
As our time is limited, it is not necessary for me to make any extended remarks. We have decided that Dr. Dalyrymple, of Louisiana, shall make the opening talk to you on the general subject of tick eradication in the South.

\section{DR. W. H. DALYRYMPLE, STATE VETERINARIAN OF LOUISIANA, BATON ROUGE, LA.}

Dr. Dalyrymple. Mr. Chairman and members of the committee, I had the honor and privilege seven years ago of appearing before this committee, when the first appropriation was made for this tickeradication work, and I wish to express our appreciation of the generosity of the committee and of the National Government in appropriating the money at that time. Since that time the South has cleared and placed in the free area something like 165,000 square miles of territory, notwithstanding the crude methods adopted then and the gross ignorance that prevailed among some of our people. It would seem almost ridiculous to mention some of those instances, but we find people, even to-day, who will tell you the Lord Almighty sent the ticks there and it is wrong to eradicate them. That will give you an idea of the class of people, or some of them, that we have to educate to-day. But these obstructions are being eliminated, and to-day our people are demanding this work. We are here at the behest of our southern agriculturists to obtain, if possible, some more money to carry along this work. They wish the work carried along. They are asking us all the time now what we can do to get this tick eradicated and to enlist the assistance of the Government, and, as I remember, I believe Chairman Lamb was a member of that first committee when the precedent was set that those who helped themselves would get the help of the Federal appropriation, and I think that in some of the cases, some of the States are really spending more in their own States than the Federal Government is.

This tick-eradication work is the simplest thing possible. I do not know of another disease that can absolutely be stamped out except this Texas fever, because it is, if you will permit the expression, a two-host organization; it requires two individuals through which to complete its life cycle, just like the yellow fever, which we stamped out in New Orleans in 1905, and by destroying the one host, the tick in this case, we simply cut short the fever. The very fact that 165,000 square miles of territory has been cleared and is to-day in the free area is evidence of the fact that this thing can be done. It seems a pity to temporize with the thing, since it is possible to absolutely stamp it out. In the case of tuberculosis or any of those diseases we do not know just when it has been eradicated or how it can be absolutely eradicated, but this question of the Texas fever of cattleand it is not a sectional question, it is a national question-it can be eradicated by the eradication of the ticks. This dipping-vat process with the standard arsenical solution is absolutely the thing to do it with. I might say it would be possible for a State, with the assistance of the National Government and with sufficient of those dipping vats for the process, following a regular system in the dipping in accordance with the life history of the ticks, to be absolutely cleared of ticks in one year. 
I said it was not a sectional question. We want the open markets of the country; that is, our one great aim is to get into the open markets and be on a level with every other section of the country. Some one said to me the other day that the high cost of living was due largely to the lack of production, the production not keeping up with the consumption. This tick in the South is absolutely prohibiting us from producing our cattle and making sale of our livestock products on the open market. We would not have this high price of cattle, $\$ 11$ per hundred pounds, if the southern country were in a position to ship those animals to the market when ready for the market, but the Government has quarantines, and will continue to keep us under quarantine until this tick barrier is entirely removed. Another thing is, we can not import our animals from the North, and we have depended on the North for a number of years for our puregrade animals, because of the fact the nonimmunes will get this tick fever when they come South. You see the northern section of the country has just as much interest in this matter, you might say, for many years to come, as our southern section of the country, and so I say it is not a sectional question. I remember that Secretary Wilson, before this committee seven years ago, mentioned the fact that this was a national question, but it is not only that, but it is also an international question, because this Texas fever first gave Germany an excuse to discriminate against our meat products.

We have no competition with other sections of the country to-day in the meat markets of the world. We are allowed to ship cattle to the northern markets for perhaps two months at the very coldest time of the year - to the Chicago, St. Louis, and other markets. Those animals may be absolutely better than a western man's stock and may have no ticks on them, but, because they come from a tickinfected section of the country they are placed in sections of the stock yards and ticketed as southern cattle, and that means that the buyers will discriminate against those animals $\$ 3$ to $\$ 5$ per head. It is estimated that something like 1,000,000 head of cattle are shipped from the South to the northern markets every vear, which shows that we are paying $\$ 3,000,000$ to $\$ 5,000,000$ tribute on account of this quarantine line, which could be wiped out, because the tick means the quarantine. So the object is to give one-third, vou might say, of this great country of ours access to those markets that other people of the country have.

Down in our country we are looking for immigration. A great many people are going down there. This great land show in Chicago, and that sort of thing, has got the people interested in that section of the country. We are getting people down there and they are the class of people we wish to get in our country-the progressive western stockmen. But when he hears about the cattle-tick business it simply stops him; he will not come. What encouragement would he have? If he brings his fine stock down and they get the ticks they will die of the Texas fever. On the other hand, if he succeeds in raising a carload or two in a year he can not get into market with them because of the quarantine. So we look upon it - the great commercial industries of the South, the railroads, and others, look upon it -as the greatest agricultural industrial problem before our country to-day. 
Mr. Maguine. To what use would you put this extra money you are asking for?

Dr. Dalyrymple. It would be expended to have Federal men come down there and assist in the systematic work of getting rid of the ticks.

Mr. Maguire. Just how would you do that?

Dr. Dalyrymple. Just as it is being done now. The question relates to the number of men.

The Chairman. Permit me to suggest that we recognize the importance of this work and have provided for it. We should like to have you gentlemen here direct your arguments to the necessity of an increase in the appropriation, and likewise give us some information touching the cooperation of your States in this work. Those are the two points upon which we should like to hear from you. The time for this hearing is limited and therefore I make that suggestion. We appreciate your argument, but if you will pardon us we will suggest that we have heard all this before.

Dr. Dalyrymple. You, Mr. Chairman, have heard it before, I know, but I do not know about these other gentlemen. The other gentlemen, from each State, I think will talk upon that matter.

The Chairman. May I inquire what amount of money your State appropriated?

Dr. Dalyrymple. We have been appropriating $\$ 5,000$ a year for the last seven years, but then our counties or our parishes, as we call them, have been giving money, and they are providing means in the way of building the dipping vats to be used in this work. I can not give the exact figures-I have not got them-but that is the amount of State money.

Mr. Hawley. Is the dipping compulsory?

Dr. Dalyrymple. It is; yes.

Mr. Hawley. Over what portion of the State?

Dr. Dalyrymple. In our State it is compulsory in three of the nor hern parishes; it started on the northern tier of parishes, but we have carried the work forward in some of the interior parishes, and the. local people are expending the money for vats in order to educate the people in the value of the work.

Mr. Hawley. How soon do you expect this whole State to be covered by this compulsory dipping law?

Dr. Dalyrymple. We want more Federal men, we want five more, I believe, now. The estimates for the Department of Agriculture were made up in September before the real facts in this case were known, I believe. Some of these gentlemen, I think, will be able to show you that a great many more men will be required than were thought necessary at that time. It is not a question of any department of the Government wanting this. We want it, the people of the South want it.

Mr. Rubey. Do you not think $\$ 5,000$ is a small sum for your State to give?

Dr. Dalyrymple. Yes, sir; it is. That is the State appropriation. I might say that I worked 20 years to get a live-stock sanitary law. The first time we did not get any appropriation at all, but we are gradually working up to it; but the people themselves are expending money locally, which of course should be taken into consideration by the Federal Government in supplying us men. 
Mr. Rubey. But you do not know how much that is in the aggregate?

Dr. Dalyrymple. No, sir. We have one patch clear of ticks. We took advantage of the overflow of the river, and by compelling the people to dip their cattle before they brought them back into the overflowed district we freed that district from the ticks.

Mr. Hawley. Has your sanitary commission that power?

Dr. Dalyrymple. Yes, sir; we have plenary power to promulgate any rules and regulations.

Mr. Maguire. Are you in full charge of the work down there?

Dr. DAlyrymple. No, sir; I am a member of the board; we have our executive officer, in some States called the State veterinarian, I think. I give my advice, work, etc. I am connected with the State university.

I think perhaps I have spoken long enough, and I thank the committee.

Dr. CARY. The next gentleman we should like the committee to hear is Mr. White, of Tennessee.

\section{G. R. WHITE, OF NATIONAL, TENN.}

Mr. Whiтe. Mr. Chairman and members of the committee, I am not going to consume much of your time. I will say I am here in the interests of tick-eradication work in all the Southern States in general and in the interests of tick-eradication work in Tennessee in particular. There is no doubt that there exists a shortage of at least $10,000,000$ cattle now to what there were 10 years ago. Something must be done in order to stimulate the cattle-raising industry in this country or in 5 or 10 years from now the cattle shortage will amount to prohibitive prices for beef. We are very anxious to stimulate this industry in the South by eradicating the Texas-fever ticks, which work is absolutely essential in order to stimulate that cattle-raising industry. I will say that in Tennessee this work started about seven years ago. At that time there were 51 counties in quarantine on account of this tick. I have a map here that will be an object lesson to the members of this committee. The counties marked in green represent the original quarantined counties in Tennessee; that is, 51. After seven years' work in tick eradication in this State we have eradicated ticks in 44 counties, and we have yet 7 counties in quarantine on account of the presence of this tick.

Mr. Hawley. You mean that you now have 44 counties absolutely free from the tick?

Mr. White. Yes. Now, gentlemen, if the ticks can be eradicated in 44 counties in Tennessee they can be eradicated in these other 7 counties in that State, and if they can be eradicated in the whole State of Tennessee they can be eradicated in the States of Mississippi, Texas, Louisiana, Florida, Georgia, and other States that are in quarantine at the present time.

Mr. Hawley. Was your State badly infested with the ticks?

Mr. White. Just equally infected with Louisiana.

Mr. Maguire. Did your State appropriate any money?

Mr. White. Our State appropriates $\$ 8,000$ by the State, and each county appropriates. We have spent last year four dollars for every dollar the Federal Government has spent, and I must say that the 
expense of this work in the State and in the counties in Tennessee has amounted to something in the neighborhood of $\$ 30,000$ a year.

Mr. McLaughlin. Do you estimate a shortage of $10,000,000$ cattle in the entire country?

Mr. WhITE. $10,000,000$ in the entire country. Six years ago we had 10,000,000 more cattle-10,000,000 more beef cattle in the country than we have to-day.

Mr. McLaughuin. What is the shortage in the States that are infested with the ticks?

Mr. White. I could not answer that. I have not the figures by States.

Mr. Maguire. Is it not true that shortage comes largely in the range country?

Mr. White. It may be, but if we are $10,000,000$ cattle short now, there will be a shortage of 15,000,000 five years from now. But, gentlemen, this whole question resolves itself into a question of men and money. There is nothing else to it, and we think that if these ticks can be eradicated from the Southern States in 5 years, there is no necessity to let this work drag along for 15,20 , or 25 years.

Mr. Lever. What type of men do you use in the dipping process?

Mr. White. We use stockmen and good reliable men that are appointed by the county courts.

Mr. Lever. At what salaries?

Mr. White. The county inspectors get $\$ 60$ a month; the State inspectors get $\$ 75$ a month; and the Federal Government inspectors, I do not know what they get.

Now, gentlemen, that is the situation in Tennessee, and, of course, this appropriation will not affect us in particular, because we are going to eradicate the ticks within the next 12 months whether this increase in appropriation is made or not; but it will affect the other States to eradicate this tick, and we are very much interested in the eradication of this tick in the States south of Tennessee, because it will protect us from reinfestation.

Mr. Hawley. Has any county which you cleaned out become reinfested with ticks?

Mr. Whiтe. There never has; and I might say we have one county, one of the Georgia border counties, and we thought that had become reinfested, but we made a reinspection of all the cattle in that county and we found but two farms in the county that were infested with the tick.

Mr. McLaughlin. After you have eradicated the ticks in a county can you let it alone? Do you not have to continue the work?

Mr. White. We have to keep watch of it until we get it all clear south of there, but there is no way for it ever to become infested any more, unless ticky cattle are brought in.

Mr. McLaughlin. Just one other question. You say you found the method of eradicating the ticks successful, and that it now is just a question of men and money?

Mr. White. That is all there is to it.

Mr. McLaughum. There is quite a strong feeling prevailing that when the Government has demonstrated the method of eradicating the ticks and has shown the people just how it can be done, and that it is reducible to a question of time and money, that it is then up to the local people to do the work themselves. 
Mr. White. That is for you people to say.

Mr. MoLaughuin. What do you think of it?

Mr. White. I do not think anything of it at all. I believe you folks ought to stay behind us and help us until we get out of it.

Mr. Lever. Is it not a fact that the Government put you into it?

Mr. White. They put us into it, and we want them to help us out.

Mr. MoLaughisn. Who put you in?

Mr. White. The Federal Government put us in quarantine.

Mr. McLaughlin. They did not put you into trouble.

Mr. White. You will observe by reference to the last annual report of the Chief of the Federal Bureau of Animal Industry that there are $10,000,000$ head less beef cattle now than there were six years ago. This shortage of cattle plays an important part in the high cost of living at this time. Unless something radical is promptly done to stimulate cattle raising in the United States there will be no limit to the cattle shortage 5 or 10 years from now. In my opinion the whole population of this country must look to the Southern States for increased cattle production. Unless and until the southern cattle tick is eradicated profitable cattle raising in the Southern States is out of the question; it is utterly impossible. With the tick eradicated there is no good reason why the Southern States could not raise $10,000,000,20,000,000$ or even $50,000,000$ more cattle annually, in which event the high cost of living, particularly the meat feature of it, would be solved.

The Chief of your Bureau of Animal Industry says:

The time has come when we must conserve our meat supply and take steps to increase it, and at the present remunerative prices for food animals it is probable that this will be gradually accomplished. Farmers generally, and especially those in the corn belt, should take advantage of the situation to develop cattle feeding under the present favorable conditions. The South has great possibilities for the future in this respect. The mild climate, the long grazing season, and the cheap land in this section make it highly suited for the purposes of beef production. This has been proved by the cattle-feeding experiments of this bureau in cooperation with the Alabama. Experiment Station. There is, however, one drawback-the presence of the cattle tick. Fortunately this pest is being gradually but surely removed as a result of the energetic work of the Government and the several States involved. The development of cattle raising in the South should closely follow the extermination of the ticks.

It was eight or nine years ago when Congress made its first appropriation for this work. The results which we have accomplished in Tennessee should be an object lesson to the members of this committee and should convince you and each of you of the great and crying necessity for an increased appropriation to push this work to completion at the earliest possible date. An increase of $\$ 500,000$ would be only a meager contribution on the part of the Federal Government to the Southern States in their present feeble though earnest struggle to eradicate this great handicap to their cattleraising industry.

When tick-eradication work started in Tennessee eight years ago we had 51 of the 96 counties in quarantine. Now we have only 7 counties and parts of counties in quarantine. That means that, even though handicapped and hampered as we have been, ticks have been entirely eradicated in 44 counties.' If ticks could be successfully eradicated in 44 counties in Tennessee, then they can be eradicated in these remaining 7 counties. If ticks can be eradicated from the 
whole State Tennessee, then there is no reason why they can not be entirely eradicated from North Carolina, South Carolina, Georgia, Florida, Alabama, Mississippi, Louisiana, Arkansas, Oklahoma, and Texas. Our results demonstrate to any thinking mind what can be done when the Federal Government cooperates, even to a slight degree, with the States and counties in their warfare against this parasite. If the Government aid had not been forthcoming, tick eradication would have never been taken up in Tennessee and long before now the whole State would have become infested and placed south of the quarantine line. We have already demonstrated the possibility and feasibility of tick eradication. The whole problem resolves itself into a question of, "Men and money." Why allow it to drag along for 15 or 20 years when the task can easily be completed in 5 or 6 years, in which event every State in the Union will reap the economic benefits which will rapidly accrue therefrom?

Dr. Cary. We next wish to present Mr. Bahnsen, of Georgia.

\section{STATEMENT OF DR. P. F. BAHNSEN, OF ATLANTA, GA., VETERI- NARIAN OF THE STATE OF GEORGIA.}

Dr. Bahnsen. Mr. Chairman and gentlemen of the committee, there is very little I could add to the statements which have already been made. In the State of Georgia we had, up to last year, a tick appropriation of only $\$ 500$, and the Government spent more money than the State did, and consequently the work in Georgia progressed very little last year, and I want to say that tick eradication was not popular to start with in the State of Georgia, and is not popular now with some people. They did not seem to think that the cattle tick hurt their cattle at all, and we sometimes find cattlemen even now in the tick belt who laugh at the idea that the cattle tick hurts cattle or is hurting the cattle industry. As a general rule, however, they have found it is essential to do this work, and they have generally taken hold of it now. Last year the last legislature appropriated $\$ 15,000$ for extending the work of cattle tick eradication. In addition each and every county we have has contributed very liberally or has made an appropriation. I will cite the example of Walker County, which is one of our border counties. The county commissioners provided funds for constructing 32 dipping vats, and agreed to put them all in operation before June 1. That is only one county. Other counties have done nearly as well; not quite so well, but nearly as well, and in addition to that they agreed to furnish us a man to do this work. We know this work has to be supervised by men who are trained veterinarians in order to get the results. The actual work, replying to question Mr. Lever just asked, is invariably done by just practical men that we employ as cattle inspectors; then they are supervised in their work by trained veterinarians; these trained veterinarians have been furnished by the Federal Government, but last year we only had 4 at our disposal, when, as a matter of fact, we should have had 14 . No one man can look after more than one county. Next year we should have at least 20 veterinary inspectors, in order to keep the work going, and unless we get an additional appropriation we are not going to be able to get more than 4 , or possibly 5 . 
Mr. Lever. Just how much additional appropriation do you want?

Mr. Bahnsen. For the State of Georgia?

Mr. Lever. No; I mean for the entire country.

Mr. Bahnsen. On yesterday, in conjunction with Dr. Melvin, the committee figured that out, and on a reasonable estimate we should have between $\$ 675,000$ and $\$ 750,000$ in order to not hamper the work. Other States will speak for themselves. I am sure they will make the same statement we have made from Georgia. Last year our work was handicapped because we did not have the cooperation. we really expected.

Mr. RubeY. How much money did your State get from the Government last year?

Dr. Cary. $\$ 250,000$.

Mr. Rubey. I mean, how much did the State of Georgia get?

Mr. Bahnsen. I think we got between $\$ 10,000$ and $\$ 11,000$. The State - that is, the State and the counties together-spent approximately $\$ 3$ to the Federal Government's $\$ 1$.

Mr. RUBEY. I notice here there was an appropriation last year of $\$ 250,000$, and you say the State of Georgia, of that sum, got $\$ 10,000$ or $\$ 11,000$ ?

Mr. BAHnsen. The State of Georgia got $\$ 10,000$ or $\$ 11,000$.

Mrr. Lever. With this appropriation you are asking for, if the committee should allow it and Congress should allow it, how long would it take you to clean up this infested territory?

Mr. Bahnsen. That was well stated by Dr. Dalyrymple. If we get sufficient cooperation so we can extend this work, then there would be no need of prolonging the work of tick eradication. Under such cooperation the fever ticks ought to be eradicated from the entire country in less than five years, if we get after it as we should. It is merely a question of men and money.

Mr. Hawley. Have you the power, under the laws of the State of Georgia, to compel people to dip their cattle?

Mr. Bahnsen. Yes, sir.

Mrr. Hawley. Suppose they do not dip, do you dip at their expense and charge it to them or do you destroy the cattle?

Mr. Bahnsen. Our law gives us authority to quarantine their cattle and for compulsory dipping. If they fail to dip, we prosecute them for a misdemeanor, and I want to say that the courts have backed us up in each of the instances. Whenever we get a man before the courts for a violation of the quarantine law they never fail to fine him. Of course, the fines are merely nominal- $\$ 10$, $\$ 15$, or $\$ 25$, and costs-but we find in every instance it is sufficient to make them come right up.

Mr. Hawley. The people fined, then, have their cattle dipped?

Mr. Bahnsen. Either that or they remove them without receiving a permit.

Mr. HAwley. I mean after you have prosecuted a man for not dipping his cattle and then he is fined, does he then dip his cattle?

Mr. Bahnsen. Yes, sir; they do not fail to do it after they have been through court once. 


\section{STATEMENT OF HON, R. F. KOLB, COMMISSIONER OF AGRI- CULTURE, OF THE STATE OF ALABAMA.}

Mr. Kolb. Mr. Chairman and gentlemen of the committee, I can only, in a few words, emphasize what Mr. White, of Tennessee, saidthat the need of my State and of the whole South is more money and more men. The statistics of the United States show that over $\$ 5,000,000$ was lost in Alabama by infested cattle. We are losing that much annually. I claim for my State of Alabama that we are doing more in the interest of agriculture, as a State, that is, in the appropriation of money by the State, than any other Southern State, if not more than any other State of the Union. Our last legislature appropriated $\$ 25,000$ from the funds of my department for this farm demonstration work in conjunction with the United States Government Department of Agriculture. I pay those demonstrators every month three-fifths of their salary; the Government only pays two-fifths. In that way we are carrying on this great work in Alabama. It is the same way in the soil-survey work. Alabama is giving more money out of her treasury than any other State in the Union.

The Chairman. Yes; you are right about that.

Mr. Kolb. I know, because the funds come from my department. The Government puts in four surveyors in my State, and I put in four, and we are working four counties at a time, and we appropriated $\$ 10,000$ for that purpose. We have no direct appropriation from the treasury or from my department for this tick eradication but, the countios are doing a great deal all over the State of Alabama and yet we are in this lamentable condition.

Mr. Rubey. Could you give us an estimate as to the amount the counties give for this purpose?

Mr. KoLB. I presume the whole State-

Mr. CARY (interposing). I think last year the counties gave about $\$ 25,000$.

Mr. KolB. The counties gave about $\$ 25,000$. In a great many of the counties they are building from 30 to 40 of these vats.

Mr. RuBEY. Do you know how much the Government has appropriated for Alabama?

Mr. Cary. Alabama got $\$ 6,000$ to $\$ 8,000$.

Mr. KolB. Now, gentlemen, it is up to you, and then to Congress, and you ought to relieve us, and I believe you will.

Mr. Young. Do any of your individual cattle raisers have their own dipping vats?

Mr. Kolb. Yes, sir. I can cite you to one farmer, Mr. F. D. Derby, who has a large farm, and he offers $\$ 1,000$ to any man who can find a tick on any of his cattle, and he raises a great many cattle. He has the ticks completely eradicated, and yet we have got the quarantine taken off of only one county, and that is not off yet, but it will be this month or next.

Mr. Lever. What is the cost of these vats?

Mr. KolB. From $\$ 25$ to $\$ 75$.

Mr. McLaughlin. They average about $\$ 35$ apiece.

Mr. KolB. What we want is the money and men to help us. We can raise as fine cattle in Alabama as can be raised anywhere in the South or East, and we want help to let us get rid of the cattle ticks 
Mr. Cary. We next wish to present Mr. Archibald Smith.

\section{STATEMENT OF MR. ARCHIBALD SMITH, OF THE STATE AGRI- CULTURAL COLLEGE OF MISSISSIPPI.}

Mr. Sмiтн. Mr. Chairman and gentlemen of the committee, I wish to outline to you very briefly the status of this work in our State. It began 5 years ago with an appropriation of $\$ 5,000$ on the part of the legislature for 2 years. As a result of those 2 years' work the !egislature then appropriated $\$ 40,000$ for this work, and last year the legislature appropriated $\$ 35,000$. We get a larger appropriation for this work than any other State in the country, and we are working a larger area and clean up more territory. As a result of our work we have 8 counties free from the ticks.

Mr. Candler. State how much you get from the Government in Mississippi.

Mr. Sмiтн. This last year we got the services of 15 to 20 veterinarians. I do not know what salaries are they paid.

Mr. Rubey. You do not know how much money the State of Mississippi received from the Government, do you ?

Mr. Smith. It received the services of that many men-between 15 and 20 men.

Mr. Candeer. Does this work probably get more from the State or more from the Government?

Mr. Smith. The State appropriates more money than the Federal Government, and the counties appropriate more money than the State. During these last two years the counties have expended a little over $\$ 150,000$ for the building of vats alone, and the counties in Mississippi this last year expended a little over $\$ 50,000$ in the employment of inspectors, so that the counties are spending a great deal more money than either the State or the Federal Government. As a result of our work we have 8 counties above the quarantine line, and we have an area equal to about 8 or 10 counties ready to be released now.

Gentlemen, this is a much more serious problem with us than it is in some other sections, because over one-half of the State of Mississippi is infested with the boll weevil. That means that cotton growing with us is less profitable. We have a great number of men in the employ of the Federal Government in that section of the country teaching the farmers better systems of farming and advising them to grow other crops than cotton, and so on. All we want to do, gentlemen, is to get permission to enable these farmers to utilize the opportunities they have. In other words, we want to exterminate the cattle tick, so when they grow these other crops than cotton they will have some means to utilize them. If we had the cattle tick out of that country it would beat the great feeding grounds of the cheapraised cattle of the West. I Last year the board had money to appoint men in 22 counties. There were over 30 counties asking for men that we could not help and that the Federal Government could not help. Gentlemen, we want to help the men in these other 30 counties. We are carriyng on the work now in over 50 counties in Mississippi, but we only have direct appropriations to help them in 20 counties. We want to help these other 30 counties, and, gentlemen, if you knew the conditions in these boll-weevil areas in that country, if you knew its 
influence on land values, you would not hesitate to be very generous in your recommendations. I look upon this appropriation as being very different from an ordinary appropriation. It is not one that will continue indefinitely or increase from year to year. If you follow your present custom you are eventually going to appropriate money enough to eradicate the ticks, and it is only a matter of appropriating more money than you have heretofore done and to do it at an earlier date and give these people more immediate relief. We want 30 more men in Mississippi to help these farmers, especially in the boll-weevil areas.

Mr. CANDler. I see from the estimates that these salaries range from $\$ 1,800$ to $\$ 2,250$. The average salary, we will say, would be $\$ 2,000$. If we had 16 men in Mississippi we would have to have somewhere between $\$ 24,000$ to $\$ 30,000$ from the Government.

Mr. Sмiтh. Yes, and I may say that those veterinarians start in at $\$ 1,400$ each, and their salaries are gradually increased, and the veterinarians used for this purpose are usually new men, who are not high priced.

Mr. CANDler. Then from your statement that we had about 15 men we are evidently doing more for ourselves than the Government is doing for us in Mississippi, is not that true?

Mr. Sмiтн. Yes, sir. And this one point I should like to impress on you, that even though the State and the counties appropriate enough money to clean up the States, we still could not get it released until the Federal Government provides a sufficient number of men to supervise each county and report its condition to the Federal bureau. In other words, the quarantine has to be released by the Federal Government and can not be released until your men supervise that district and know it is clean. So we can not make progress much faster than you will furnish men to supervise the areas that we clean up. Your men only act in that capacity. They have sort of general direction of the work, and the Federal Government practically has supervision of the expenditure of all the money appropriated by the counties and by the State as well as by the Federal Government.

Mr. Candler. In addition to that, when you once clean it up and the quarantine line is placed above it, and the territory that is cleaned up of the cattle tick is brought below it, then that appropriation for that part ceases, and ceases forever, does it not?

Mr. Sмiтн. It ceases then. The counties then provide inspectors to see that the country is properly policed from further infection. As soon as the county is released, then the Federal expenses cease.

Mr. CANDlen. Then the larger the appropriation is, the more territory you can free from the cattle tick, and it is not a continuing appropriation?

Mr. Sмrтн. No, sir; we could clean up the whole State of Mississippi next year if we could get help enough to do it. Thesentiment of the people is very much in favor of it. 
Mr. Cary. The next man we wish to introduce is Dr. Dawson.

\section{STATEMENT OF DR. C. F. DAWSON, STATE VETERINARIAN, OF JACKSONVILLE, FLA.}

Dr. Dawson. Mr. Chairman and gentlemen of the committee: I represent the State which has done nothing whatever in tick eradication. We are the only State which is wholly south of the quarantine limitation. That means we have no counties, no section, from which we can ship cattle unrestrictedly to the northern markets.

I shall be very brief, because there are gentlemen here who can tell you more about eradication from a practical standpoint than I can, because they have had experience.

We have in Florida about 850,000 animals - about the same number of animals as people, and the same number of swine. We lose annually about 3 per cent of our cattle, which means an annual loss of $\$ 25,000$, estimating the animal to be worth only $\$ 10$ a head. I wish to say that our State has only recently become particularly interested in the subject of tick eradication. One month ago we met and started the agitation for this purpose, and I think I am not making a misstatement when I say that our State will make probably a $\$ 5,000$ appropriation for beginning this work. This money will come either from the State board of health funds or be directly appropriated by the legislature. In our State the State board of health has to do with not only diseases of people, but also with those of animals, and this work is done like it is in most any other State in the Union, and Dr. Porter, the State health officer, is very much interested in tick eradication; and I think that board itself has the power to set aside a sum of money equal to what other States have begun with to start tick eradication.

There are other gentlemen here who can tell you more than I can about certain things. I simply wanted to tell you what our State of Florida would probably do, and will do, in regard to this subject.

Mr. Hawley. You have the ticks, have you?

Mr. DAwson. We have the ticks, and I believe the tick probably first entered the United States at St. Augustine, Fla. It is now all over the State. I know of no section in the State where there are no ticks. We have another disease known as "salt sick," which I believe will disappear when we get rid of the tick, because the cattle sticcumb to the so-called salt sickness in the fall of the year when the pasturage is poor and ticks are worse. Other than this we are singularly free of animal diseases. We have no anthrax, no black leg, and very little tuberculosis, except in the daries around the cities. The native cattle of Florida are singularly free of tuberculosis, so this one disease is the one which troubles us the most, this Texas fever, and I believe-in fact, I know-that if we get rid of it Florida will become one of the greatest cattle-raising States in the United States, because of our climate, which is not severe. There is no absolute winter climate there such as will kill cattle.

Mr. CANDler. It is a great State, I know. I was born there. 
Dr. Cary. I wish to introduce Mr. Chrisman, of North Carolina.

\section{STATEMENT OF DR. W. G. CHRISMAN, STATE VETERINARIAN OF NORTH CAROLINA, RALEIGH, N. C.}

Dr. Chrisman. Mr. Chairman and gentlemen, I am representing not only the State of North Carolina, but all the Southern States interested in tick eradication, and that includes one of the biggest problems now before the live-stock men and agricultural men of the South. I hold in my hand this morning a map which shows conditions in North Carolina. West of this black line is the territory which has been freed from ticks. From this part of the State we can ship cattle to any market in the United States without any restrictions; from this other part of North Carolina we can not send cattle to the open markets in this country or in any other country, because here the Federal quarantine line exists. All of this territory is filled with ticks, and we can not ship our cattle from there. The problem we have to-day is that of money and men. Give us money and men and then we can eradicate the tick from this section of North Carolina and can send our cattle all over the United States to our big markets.

Mr. Rubey. Was the western part of the State infested originally?

Dr. Chrisman. Yes, sir; this was infested, and this part [indieating] is left yet for us to clean up. The proposition now is money and men. We want an additional force of five men from the Government to supervise the work that our State men will do, because our State is appropriating about $\$ 10,000$, and will appropriate more money at this present meeting of the legislature, and in the future we will have more money to work with, but we want the United States Government men to supervise the work of our State men, because they are not trained men; they are simply businesslike farmers and practical stockmen who can drive cattle to a dipping vat and see that it is done, but they want a veterinarian, trained in his work, to know that it is properly done.

Mr. Candler. Another necessity for having men from the Government is the fact that you can not get any territory released from the quarantine until it is approved by the inspectors from the Government, is it not?

Dr. Chrisman. No; we can not, no matter how much work the State does or what we say about the work; whether our territory is clean or not, they will not take our statements until the Federal men call and see the condition. That is the proviso you have made, and perhaps it is a wise one. We have commissioned the United States inspectors so they have double authority. They have the authority which is vested in them by their commissions, given them by the Secretary of Agriculture of the United States, and Secretary Graham gives them a State commission, so your men you send there can prosecute a violator in our courts, and also in the United States courts, and we take up our violations and prosecute the men in our courts.

Mr. Rubey. How much did the State of North Carolina get from the United States Government last year?

Dr. Chrisman. Between $\$ 6,000$ and $\$ 7,000$ last year. I might say that we have not failed of a prosecution in our State of any man who has violated the provisions of this law. 
Mr. Young. How many years have you been at that work?

Dr. Chrisman. About eight years. After we have once cleaned up a county the ticks do not reappear, because we keep our force on that line watching that all the time. Our State does that.

\section{STATEMENT OF DR. J. F. STAMFORD, STATE VETERINARIAN OF THE STATE OF ARKANSAS, FAYETTEVILLE, ARK.}

Dr. Stamford. Mr. Chairman and gentlemen of the Agriculture Committee, I wish to say for the State of Arkansas that we are making rapid progress toward complete tick eradication. We have now within our State an area consisting of 11,003 square miles free from tick infestation, and to-day above the national quarantine line. I wish also to state that 1,161 of these square miles was freed from tick infestation through free contributions from our land owners, planters, and citizens. Not one cent was sent there from the State at large, or from the United States Government. all ?

Mr. RubEY. Do you mean you have not had any money sent at

Dr. StamFord. I mean in these 1,161 square miles. We spend annually about $\$ 15,000$.

Mr. Rubey. How much did you get from the Federal Government last year?

Dr. STAMFord. About $\$ 10,000$. Three thousand dollars of this $\$ 15,000$ was from private contributions, made up by the citizens and land owners in the section of country previously engaged almost exclusively in growing cotton. They have found that the one continuous one-crop method, that of growing cotton, is detrimental to that great agricultural interest. What we want now is an increased appropriation from the fact that we are receiving demands and pleadings from citizens in counties far off from our present fixed eradication districts, asking us to take up the work in their midst. Congress in the past has aided greatly the South in removing this, the only hindrance to our agricultural pursuits, but the work has far outgrown the appropriations made by Congress in the past, and we now ask that you increase this appropriation in proportion to the demand of the work.

I believe our time is about up, in fact my time was called ahead of the hour we were given, so this is all I shall have time to say. I thank the committee for their attention.

Mr. Cary. Mr. Chairman, will you just give me a moment to close this hearing?

The Chamman. Yes, sir.

Mr. CARY. As chairman ol the Southern Agricultural Workers, that brought this work before you, we met with the Chief of the Bureau of Animal Industry and with the Secretary of Agriculture vesterday and went over the estimates we had made to you in September, and also got reports from the various States as to their wants for the coming year. We find, in adding up the estimates of wants of men in all the different States, that the sum total was 150 veterinarians for the entire South for the coming year; that includes States you have not heard from to-day, such as Scuth Carclina, Oklahoma, Texas, etc. These 150 men, as figured by the department, will call for about $\$ 375,000$ to $\$ 400,000$ additional. That is what 
it means. There is no use, as has been said here to-day, in temporizing with this. If we are going to do it, let us do it and get through with it. We can do it in a few years if we put the men behind the work.

One word more. This work has been going on along the northern line of counties. Along this line the work has progressed rapidly, but from now on it will require work the year around, instead of work just in the summer. The men can be set on the work full time, and there will be a little more expense in connection with each man. They figured yesterday that it would take $\$ 2,500$ to put one of these men in the South for a year, so we have about 150 required for the full year, and the estimate of the department was about $\$ 400,000$ extra.

Mr. Candler. At the first hearing had before this committee, away back yonder, in reference to this question, it was shown at that time by the statistics that the difference in the value of cattle in the South, by reason of the cattle tick, was a loss to the South of some $\$ 60,000,000$; that was the estimate. Do you know how much is cleaned up now, and what the proportion is now?

Mr. CARy. About one-third of the infested area is cleaned up, about 70,000 square miles, about one-third.

Mr. RUBEY. How long have you been in doing that?

Mr. CARY. We have been doing that about six years, but a good deal of this work has been pioneer work, as they had to teach the people a great many things that will be much easier for them from now on.

Mr. Ruby. Cleaned up one-fourth ?

Mr. CARY. I only gave the estimate as made by the department; that is what is claimed in the report.

Mr. Maguire. I should like to ask of you, as an expert and a veterinarian, whether you have arrived at the bset methods of eradicating the tick, or is it simply still in the experimental stage?

Mr. CARY. It is no experiment at all; it is a positive, definite method, and actually doing the work thoroughly and completely. There is no doubt about the method any more.

Mr. Candler. If these original estimates were correct, that $\$ 60,000,000$ was lost to the South, and there is one-third cleaned up, there is still a loss of at least $\$ 40,000,000$ a year.

Mr. CARY. Yes; no doubt. That is probably a low estimate, because the class of eattle has improved since that first estimate was made.

Mr. RuBey. I want to ask, for information, what kind of cattle you have in the South. Do you feed cattle for the market in the South? Mr. CARY. Some.

Mr. RUBEY. What is the average weight of a steer that is ready for the market?

Mr. CARY. The average weight of a steer that comes off the range runs anywhere from 600 to 700 pounds.

Mr. RUBEY. The feeding steer when you ship him to market, will he average 1,000 pounds?

Mr. CARY. About that, I judge.

Mr. RuBEY. About 1,000 pounds?

Mr. CARY. The steer, the steer where they feed him?

Mr. RUBEY. That is what I mean, a fed steer.

Mr. CARY. Yes; some of those will run that. That might be a little high for an average, but somewhere near that. We thank you, gentlemen, for the hearing. 



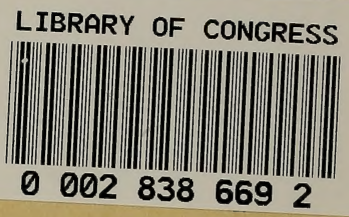

